Kohl: a Journal for Body and Gender Research

Vol. 2, No. 2 (Winter 2016)

\title{
The Road to Dissent
}

Gemma

Edited by Ghiwa Sayegh

This oral testimony was part of a recorded conversation between migrant domestic workers living in Lebanon. 
I came to Beirut in 1993. But before that, I was a teacher in the Philippines. I am a teacher. I was running a daycare center, and I was the pioneer in doing so in my municipality. It was one of my projects. What drove me really to come here to Lebanon is the human thinking it is always greener on the other side of the fence. We always tend to think that way. During that time in 1987 , I started my project and it succeeded, but I was earning $80 \$$ a month, and I have three children. My husband and I had a farm. It is a hard life being a mother of three children and having no companion to help you with the house chores. I had to attend to the three children, do the household work, and help my husband in the farm. It was too much. I gave all you could imagine, did every single small job you could think of. Any work that would bring a cent, I did. I was an agent for Playtex, the lingerie, I was an agent for Tupperware, I ran a little eatery... I have no idea how I divided my time back then. I had to wake up at 5am to prepare everything for my children, cook their lunch, and at 8am, I had to be at the center. I did not have a car at that time, so I had to walk to the center and back, and the center was a bit far - the distance was more or less like from Ashrafieh to Dora. ${ }^{1}$ My physical body was so tired. I asked myself: "is this the life I will have until I die?" It was so hard, and I was so tired. So I told my husband one day: "how about me going out of this country to look for a better job, a better income?" He said no. But why not?

I was lucky - no, not lucky. My mom was in Lebanon. She is the age of Mala, ${ }^{2}$ and she, too, immigrated to a Lebanon at war, but she was fortunate that her employers took her with them to Europe during the war. That is how we managed to have constant communication during my youth, because otherwise, it would have taken six months to receive a letter from her. I asked my mom whether she thought I could have good work if I came to Lebanon, because I know, I know that domestic work is not a big deal. I am teacher, I came out of university, I did my project, but I know because growing up, we did not have a mom. I was 12 years old when my mom left us, when she migrated to Saudi, and then to Lebanon. So domestic work is not strange for us, because we did it while we were growing up. Nobody would wash for us, iron for us, cook for us. We had to do it for ourselves. We had to wash the dishes, we had to fetch water because we did not have a water pressure pump, unlike now. Back then, we had to carry the water and store it in the kitchen. So I asked my mom if she could look for an employer for me in Lebanon. She was worried about me leaving my three children behind, but I was convinced that they would be okay with their father and that he would take good care of them. My sister, who had just graduated from university, wanted to come along. She said: "if you are going, I am going." I asked her whether she did not want to practice her profession in the Philippines instead, and she argued: "you didn't practice your profession." So we both set off for Beirut.

The employer of my mom sponsored me, because in 1993, direct hiring was still possible. You did not need an agency. My sister's sponsor was the cousin of the family. Before coming, the initial processing of the papers was not a problem in the Philippines, as we had legal documents. We went to a governmental agency and listed our names, and they gave us a pre-departure orientation seminar: what to expect here in Beirut, what is to be called a domestic worker. They taught us how to operate the washing machine, the dishwasher, what is a flat iron, what is a microwave...

\footnotetext{
${ }^{1}$ Ashrafieh and Dora are two neighborhoods in Beirut, separated by no less than $2 \mathrm{~km}$.

2 You can read Mala's testimony at: http://kohljournal.org/migrating-to-civil-war/
} 
We reached Beirut. We had to wait for our sponsors to come pick us up. We stayed in that room. That filthy dirty room, where all nationalities of domestic workers are crammed together. Then the employers came to fetch us. The shock, upon leaving the airport. All the buildings of Tarik al Matar ${ }^{3}$ were falling apart. The Civil War had only ended a couple of years ago. While the car was driving past them, you had the impression that they would fall on you. The city seemed like a jungle of shattered cement and iron bars hanging loosely. We were lucky because our mom was already here. She kept us that day, and she cooked for us, and she pampered us. We did not sleep all night to catch up, recapping our lives. My mom worked in Saudi for two years, and during that time, we only received two letters. When she came back, she said that her life there had been horrible. She was a picky person for food, so she survived on watermelon for two whole years. Then, she stayed in Lebanon for 18 years with her employers. They were ok, but it is the same story as ever - the money issue. Employers cannot give you a raise, they never give you a raise. There is a margin of saying "you are domestic worker, this is how much you can reach in terms of salary." So after 18 years of work, my mom was receiving only $400 \$$.

18 years, $400 \$$.

When I came to Beirut, I saw how my mom had been working most of her life. She lived with an employer with a three story house, and she was doing all the housework on her own. You can just imagine how much work that is. The family had dinner invitations twice a week, so she cooked, cleaned the three floors, and took care of the child. I could not imagine how my mom, my own mom, had lived, how she was still living, and she wasn't young anymore. I was assigned to the care of the mother of the employer for $300 \$$ a month. I took care of the lady, but we could not understand each other due to language barriers. At that time, I did not understand Arabic - I still don't. I decided to find a job more suitable for me, an employer who suits me, whom I will understand. I wrote a 4 pages on yellow paper describing what I wanted, and I went to the employer, the "mister,"4 with my guidelines.

- Sir?

- Yes?

- Can I tell you something?

- Yes. You wrote down what you want to tell me?

- Yes, because I don't want to miss anything.

I explained everything and he listened. I said it was not that I was unhappy with him, but I wanted to look for another job, someone I could understand, who could understand me, someone who would work together with me. He agreed, but asked me to reimburse what they had spent on me to come to Lebanon. It was a deal.

\footnotetext{
3 Literally, "Airport Road," a highway from Lebanon's airport to the center of Beirut.

4 "Madam" and "mister" are the terms migrant domestic workers are asked to use to refer to their employers.

Employers are rarely called by their names.
} 
My mom was nervous and worried that something would happen to me outside, 5 because she had heard many stories about freelance people and the hardships they go through.

Mom, I came here for money. I didn't come here for good people. Please understand me. I'm not leaving you mom because I don't want to stay with you. On the contrary, I love to stay with you. But I want, in the course of time, maybe a year or two, when I am fine, for you to go back home. And stay with dad. And stay with my brother and my children because it has been a long time. You were not there for 18 years, and we have missed you so much. Go and catch up some time. Dad is sick, and you are not getting any younger.

She understood.

I stayed with a friend in Rabiyeh, a friend who was a nanny, a domestic worker, and all the care job titles, because her employer was a divorced woman. But she had a room on her own.

I was recommended to an employer who saw my work. Apparently, I was good - I impressed her. When she interviewed me, the employer asked me how much I wanted as a starting salary. I said: "I'm not here to tell you, madam, how much I want. It is up to you to pay what services I offer you. You will pay me according to my performance." It was a deal. I started working for her, and I had heard her say already that she would pay me $350 \$$ a month. Apparently, I impressed her and she liked me. Her 5-year-old daughter was already incredibly attached to me from the first day. So at the end of the month, she gave me an envelope. My salary. She did not give it by hand, she was professional. They were good people. When I opened the envelope, there was $500 \$$ inside. No domestic worker was earning that much in 1993. $500 \$$ as a starting salary. Suddenly, I was taking care of everything in her household.

It went on, and on, and on.

But I was the problem. I was homesick and longing for something else. It wasn't just the work I was doing as a domestic worker. After two years, I wanted to go back home. Meanwhile, I had sent my mom back already since I was earning that much. I sent her home to be with my dad. I left for the Philippines and told my "madam" I did not want to come back. Khalas. ${ }^{6}$ But I was bribed with money. "What do you want?" she asked. "I will give everything you want as long as you come back." And the little child was crying, begging me to come back and telling me I was her second mother. They increased my salary by $200 \$$. Who doesn't want that money? Especially when money is the reason you leave your country and your children in the first place. But still, there was an emptiness inside of me that I could not explain. My "madam" went as far as bringing my husband to Lebanon so that I would feel less lonely. Unfortunately, he could not bear to fight the struggles of life with me, and he left me for another woman. It's okay. I cried of course. It was not okay, but now it's okay.

\footnotetext{
5 For migrant domestic workers, working "outside" means not living with and working for a single family. Instead, they rent their own rooms and work per hour in many houses.

6 "Enough" in Lebanese dialect.
} 
That emptiness that crept inside me.

I became a Filipino community organizer to battle the emptiness. I started organizing in my neighborhood and used my days off to that end. I saw that so many women were mistreated - something had to be done. That was what was missing. That was what I was missing. So I started mobilizing the Filipino community. And the years passed. My colleagues and I created PhilBall, the Basketball Filipino team in Lebanon - it has been running for 16 years now - and volleyball teams for men and women. We motivated other domestic workers, creating leaders who could take over when we leave. In 2006, during Israel's war on Lebanon, I was part of a rescue team, and we rescued domestic workers from different nationalities - Bangladeshis, Sri Lankans, Filipinos... Wherever we went, we saw domestic workers who had been left behind by their employers, locked in houses and left to die. We took them with us to our shelters and called their respective consulates and embassies. I said, this is it. This is what I want. This is when I started working in a transnational group - it has been 10 years already. This is when I really understood that domestic workers are not only Filipinos. That domestic workers are the same. That domestic workers are not labeled as Filipinos or Cameroonians or Malagasy or Sri Lankans, but as domestic workers. They are domestic workers first and foremost. When I realized that, I knew we could do something. We could do something out of it together. And this is where we are at today. 